\title{
REFERENCES
}

1. Zahaykevych A. (2008) Ukrainian electronic music: research practice. Music in the Information Society. Kyiv: Nats. muz. akad. im. P. I. Chaykovskoho, 76. 39-62 [in Ukrainian].

2. Lehenkyy I. Yu. (2016) The phenomenon of pluralization of the nonconformal movement in the polystylistics of musical culture of Ukraine in the late XX early XXI centuries. Actual problems of philosophy and sociology: scientific and practical journal. 11. 76-78 [in Ukrainian].

3. Nikolayi H. (2010) Ukrainian piano music as a phenomenon of culture of the twentieth century. Ars inter Culturas. 1. 121-132 [in Ukrainian].

4. Opanasyuk O. P. (2011) Stylistic dynamics and peculiarities of the development of Ukrainian music from the XXth to the beginning of the XXI centuries. Actual problems of history, theory and practice of artistic culture. Kyiv.: Milenium. 26. 209-219 [in Ukrainian].

5. Sadovenko S. M. (2010) Neo-folklorism in the context of musical culture of Ukraine in the second half of the 20th - the beginning of the 21st century. Culture and modernity: an almanac. Kyiv: Milenium. 2.173-177 [in Ukrainian].

6. Syerova O. Yu. (2014) Stylistic valency of minimalism in the Ukrainian musical space. Art scenes notes. Kyiv.: Milenium. 26. 48-56 [in Ukrainian].

7. Cherkashyna-Hubarenko M. (2009) Ukrainian music in modern media space: fragments and comments. Art studies of Ukraine. 10. 78-82 [in Ukrainian].

Стаття надійщла до редакції 07.06.2016

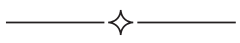

УДК 929:130.3/784+159.923

Анна Вікторівна Палійчук, викладач кафедри естрадного співу

факультету музичного мистецтва

Київської муніципальної академії естрадного та циркового мистецтва konuschenko65@gmail.com

\section{НОЕМАТИЧНІ ПЕРЕДУМОВИ СТИЛЬОВОГО МИСЛЕННЯ В. ІВАСЮКА}

Мета роботи полягає в розробиі ноематичного підходу до музичного стилю та особливостей стильового мислення В. Івасюка. Методологія дослідження визначається феноменологічним, зокрема ноологічного прямування, методом та мистецтвознавчими естетико-стильовим й семіологічним підходами. Наукова новизна зумовлюється розвитком ноематичного напряму вивчення музичного стилю, визначенням своєрідності

(c) Палійчук А. В., 2016 
ноематичних координат авторської популярно-пісенної творчості, категорізацію понять часу та «герою свого часу» у відповідності до стилю В. Івасюка, уточненням поняття стильового мислення. Висновки. Виявляються смислова предметність стилістичних означень та стильових узагальнень, головні діалогічні стильові тенденції пісенної творчості В. Івасюка.

Ключові слова: ноологічний підхід, ноема, стильове мислення, час, музична мова.

Paliychuk Anna, teacher of the pop music department faculty of musical art Kyiv Municipal Academy variety and circus art

The noamatic preconditions of style thinking of $V$. Ivasyuk

The purpose of the work is a developing a noematic approach to the musical style and features of the stylistic thinking of $V$. Ivasyuk. The methodology of the research is determined by the phenomenological method, in particular, the noological orientation, and art-study aesthetic-stylistic and semiological approaches. Scientific novelty is determined by the development of the noematic direction of studying the musical style, the definition of the originality of the noematic coordinates of the author's popular and song creativity, the categorization of the concepts of time and the "hero of his time» in accordance with the style of $V$. Ivasyuk, clarification of the concept of stylistic thinking. Conclusions. The semantic objectivity of stylistic definitions and stylistic generalizations, main dialogical stylistic tendencies of the poetry of $V$. Ivasyuk is revealed.

Keywords: noological approach, noema, style thinking, time, musical language.

Палийчук А., преподаватель кафедры эстрадного искусства факультета музыкального искусства Киевской муниципальной академии циркового и эстрадного искусства

\section{Ноэматические предпосылки стилевого мышления В. Ивасюка}

Цель работы заключается в разработке ноэматического подхода кмузыкальному стилю и особенностям стилевого мышления В. Ивасюка. Методология исследования определяется феноменологическим, в частности ноологического направления, методом и искусствоведческими эстетикостилевым и семиологическим подходами. Научная новизна обусловлена развитием ноэматического направления изучения музыкального стиля, определением своеобразия ноэматических координат авторского популярно-песенного творчества, категоризацией понятий времени и «героя своего времени» в соответствии со стилем В. Ивасюка, уточнением понятия стилевого мышления. Выводы. Обнаруживаются смысловая предметность стилистических определений и стилевых обобщений, главные диалогические стилевые тенденции песенного творчества В. Ивасюка.

Ключевые слова: ноологический подход, ноэма, стилевое мышление, время, музыкальный язык. 
Актуальність проблематики та напряму їі розкриття й вирішення в даному дослідженні зумовлена двома основними факторами. Поперше, стильовий зміст музики як необхідної частини культурної дійсності потребує поглиблених критеріїв теоретичної оцінки, що найбільше пов'язані зі смисловими категоріями, тобто з тими поняттями, котрі зумовлені намаганнями визначити складові смислоутворюючої діяльності людської свідомості - колективної культурної пам'яті. Як відомо, музичне мистецтво підкоряється особливій художньо-смисловій логіці, виробляє шляхи стильових узагальнень, що виникають з ідеаційного ноологічного осередку пізнавального процесу. Але ноологічний підхід до стилю в музиці ще не сформований внаслідок надмірної складності категорій музичного часу та музичного смислу. Цю складність можливо частково подолати, звертаючись до феноменологічних концепцій М. Бахтіна, Е. Гуссерля, О. Лосєва, Г. Шпета, з яких випливає провідне значення категорій свідомості та часу. Їх поєднання вводить до дослідницького обігу ідею переважаючої активності особистісної свідомості, відтак поняття людини як «героя свого часу», який стає взірцевою постаттю у певних культурних контекстах.

3 іншої позиції, поглибленого вивчення потребує еволюція специфічних спатіально-темпоральних показників музичної мови, яка утворює окремий семантичний вимір культурної дійсності, зумовлює множинність видів та форм музично-творчого професіоналізму, дозволяє визнавати єдність письмового та усного чинників музичної свідомості, взаємозумовленість композиторського та виконавського начал музичного мистецтва.

Мета роботи полягає в розробці ноематичного підходу до музичного стилю та особливостей стильового мислення В. Івасюка. Тому методологія дослідження визначається розвитком ноологічного методу, як найближчого до мистецтвознавчих потреб та пов'язаного 3 вивченням смислових інтенцій людської творчості, тому здатного до комплексної взаємодії з естетико-стильовим та семіологічним підходами.

Основний зміст роботи скерований, передусім, до розвитку ноематичного напряму вивчення музичного стилю. Це означає знаходження на основі феноменологічного підходу нових категоріальних визначень тих проявів надкультурної смислової реальності, що зумовлюють музичну свідомість та продовжують своє існування в особливій імагінативній формі. Серед них пріоритетними видаються ті, що дозволяють поєднувати розуміння часу, смислу та духовності, тобто 
координують оцінні виміри надлюдської та внутрішньоособистісної реальності.

До подібного поєднання низки понять спонукають спостереження Д. Леонтьєва [6], який звертається до теорій Е. Гуссерля і Г. Шпета, вилучаючи поняття ноези та ноеми, що вказують на антиномічні способи існування смислу в життєвому світі внаслідок парадоксальної природи людської свідомості.

Зокрема, Д. Леонтьєв пише: «Під ноезисом Гуссерль розуміє осмислюючу інтенціональну спрямованість свідомості на об'єкт, під ноемою - сам пережитий об'єкт як носій смислу...» Феноменологічне пояснення, - підкреслює Гуссерль, - займається нечим іншим, як тлумаченням смислу, який цей світ має для нас до усілякого філософствування - «смислу, який може бути філософськи розкритий, але ніколи не може бути змінений і який... на кожному етапі нашого досвіду містить в собі горизонти, які потребують фундаментального прояснення» [6, 14].

Своєрідно розвиваючи феноменологію смислу, Г. Шпет зазначає, що у структурі ноеми навколо «чистого смислу» формуються численні додаткові змінні значення смислу, що зумовлені логічною формою виявлення та обробки смислу. Тому ноема сполучена з «об’єктивною кваліфікацією» і «способами уявлення» того, що є ідеальним завданням смислу.

Музичне смислотворення поєднує ідеаційно-почуттєвий (відчутний) та матеріально-логічний світи художнього мислення, тому воно найбільш безпосередньо відтворює символічну природу знакової роботи людської свідомості, процесу сигніфікації.

При цьому і «чисті», тобто надмузичні, смисли є частиною культурної дійсності, входять до історичної реальності культури й зберігаються в колективній людській пам'яті. Вони належать до того виміру цієї пам'яті, котрий інтегрує та конденсує усі форми усного мововиявлення людини, тобто репрезентують континуальне мисленнєве спілкування, можна сказати, внутрішнє мовлення культурної свідомості.

Феноменологічний аспект проблеми мови культури - мови музики актуалізує парадоксальну думку К. Леві-Стросса (з книги «Мифологичные»): «Якщо музика - мова для створення повідомлень, принаймні, частина з яких зрозуміла переважній більшості, хоча лише незначна меншість здатна їх творити; і якщо серед всіх інших мов тільки ця мова об’єднує в собі суперечливі властивості бути одночасно розумоосяжною та неперекладною, - то це саме по собі 
перетворює творця музики на істоту, подібну богам, а саму музику на вищу таємницю науки про людину» $[5,38] .3$ даного висловлення прославленого антрополога можна вивести дві траєкторії подальшого вивчення музичного стилю: він має бути зрозумілим переважній більшості, якщо повинен ставати основою дієвого комунікативного процесу; він тісно пов'язаний з мовними якостями - мовленнєвими завданнями музики як сфери культурно-художнього спілкування.

Відтак постає питання про своєрідність ноематичних координат популярно-пісенної творчості, зокрема, в тій іiї авторській іпостасі, яка дозволяє композиторам і виконавцям, особливо, коли ці дві іпостасі поєднані в одній творчій особі, ставати знаковими постатями у визначеному хронотопічному культурному контексті [3-4; 8-9].

Отже, музична мова як міжлюдське спілкування, з притаманними йому конкретними історичними рисами, музичні смисли як вираження ідеаційного тезаурусу культурної пам'яті - такими є полярні величини художнього ноезису в музиці, що провокує до виокремлення і певних «об'єктивних» музичних ноем - предметів розуміння, символізації, інтерпретації, естетичної трансляції.

3 одного боку, так звана концертно-естрадна музика (у тому числі в іiї популярних формах) створює помітну сторону сучасного соціального життя, $є$ однією зі складових музичної мови культури. 3 іншого боку, у творчості композиторів шлягерно-популярної спрямованості зберігаються зв'язки з класичною мовою музичного мистецтва, i не просто зберігаються, а поновляються та відкривають нові знакові структури та семантичні функції. Мовно-мовленнєві канони класичної музики (в широкому хронотопічному сприйнятті останньої) стають предметом творчої рефлексії в популярній пісенній творчості, породжують множинні стилістичні алюзії, апелюючи до сумісної первинно-жканрової площини музичної культури в ї̈ узагальнюючому інтонаційно-словниковому значенні (тобто з залученням до неї й стильових синтагм, що набули статусу канонічних та засадничих у семантичному функціонуванні музичної форми).

Явище стильової алюзії, що виникає на основі абстрагованих від конкретної історичної ситуації стилістичних ремінісценцій, є показовим для популярної пісенної галузі музичної творчості, дозволяє виявляти закономірності їі буття в усній пам’яті культури, водночас іiї зв'язки з письмовою традицією академічного музичного мистецтва, що претендує на роль авторитарного начала та визначає обмеження у виборі та способах розвитку музично-стильового (відповідно 
й композиційно-стилістичного) матеріалу. Поєднуючи дві основні жанрово-виконавські парадигми музичного мистецтва - вокальну та інструментальну, пісенна творчість суміщає і дві їх головні семантичні настанови: природність вокального інтонування, оживленого безпосередністю людського дихання, зігрітого тембральною «теплотою» людського голосу; вибагливість та штучну ускладненість інструментального звуковидобування, здатного створювати додаткове насичене та різноманітне інтонаційне середовище навколо співаючої людини. Таким чином ноематичними чинниками пісенно-естрадного тексту (в його єдиній усно-письмовій, виконавсько-композиторській формі) постають мелодійний спів - вокальна кантилена та моторне інструментальне звучання - інструментально-інтонаційна динаміка.

В контексті музикознавчої текстології ці два начала пов'язані 3 провідними естетичними та жанрово-семантичними домінантами музики, відтак і іiі текстологічними тенденціями, причому перше 3 них відповідає ноологічній тенденції кохання - людяності, а друге поетиці гри з усіма ії̈ протиріччями та умовними вимогами.

Стосовно поетики гри як ноематичного феномена найбільш повну характеристику знаходимо у працях Г. Гессе та Й. Хейзінги, причому обидва автори погоджуються з тим, що музичним ідеалом гри $€$ класична стильова гармонія - або гармонія як провідна категорія класичної музики.

Для гри характерна ще одна художньо-комунікативна настанова - театральність, яка заснована на ігровій рольовій умовності поведінки, схожості і відмінності, зближенні і протистоянні людей, відділенні вигаданого, зіграного світу від реального - наближенні дійсного та уявленого в художньому діянні-сприйнятті, на об'єднанні індивідуальних свідомостей в акті художньої комунікації - поглибленні індивідуальних властивостей особистісної інтерпретації та смислового моделювання.

I кантиленність, і моторність можна представляти на різних рівнях музичної творчості: як конгломерати текстових формул, що входять в різні композиційні контексти; як жанрові парадигми, що зумовлюють знаково-семантичний вибір; як стильові константи, здатні підійматись над розмаїттям жанрово-композиційних форм і утворювати власний ноематичний вимір музики.

До кола ноематичних понять входять категорії, звернені до процесу семантичної репрезентації та семантичного кодування, тобто ті, що фіксують способи утворення когнітивних структур музики - 
умовно-образної і безумовно гучної. Об'єднуючим началом стосовно обох є музичний тематизм, стильові функції якого узагальнено представлені в номінаціях бароковий, класицистичний, романтичний, імпресіоністичний, експресіоністичний тощо. Очевидно, що походження і технологічне призначення стильових типів тематизму в музиці пов'язані з історичним розвитком як композиторської творчості, так і виконавської культури, спирається на ідео-образ музиканта як актуалізованої та творчо активної особистості, спроможної до естетичної гри та володіючої художніми технологіями.

Музикант, який актуалізує естетичні відношення в тематичному матеріалі музики, повідомляє нові художні значення шляхом включення в комунікативний процес власних особистісних смислів, серед яких провідними виявляються переживання-співчуття як спосіб проживання-означення часу. Створення нової умовності часу в «штучному» полі художньої реальності спирається на принципи повторення і розрізнення, як в широкому образно-стильовому, так і вузькому композиційно-стилістичному розумінні. Завдяки ним в музиці реалізуються опорні антиномії гри, до яких можна віднести, за спостереженням О. Самойленко, порядок - свободу, відсторонення - прийняття, дієвість - ілюзорність, завершеність - відкритість, серйозне - сміхове, наслідування - винахід, втілення - перевтілення, деякі інші.

Виходячи з ряду положень дослідження О. Самойленко [10], можна також сказати, що явище тексту в музиці обумовлено взаємообміном фігурно-фоновими положеннями між значеннями i «знаками», в якому фігурність значень і фоновість знаків обертаються на свою протилежність. Дана гра у сприйнятті музичного матеріалу і визначає формування і вибір семантичних кодів, тобто $є$ методично важливою в утворенні і тексту, і смислу тексту, відтак може бути визнана стильовою. Особливо рельєфно вона проявляється в неостильових напрямах, оскільки фігурно-фонова гра стильовими моделями $є$ і найскладнішою, і найбільш дієвою.

Унікальність дарування В. Івасюка, яка забезпечує йому положення й значення провідної постаті, справжнього «героя» - не лише часу, але й простору національної пісенної професійної культури, тобто постаті музиканта-пісенника, який володіє усіма сторонами та формами пісенної творчості, визначається саме домінуючим неостильовим напрямом. Майже всі дослідники естрадно-пісенної лірики В. Івасюка відзначають поєднання у ній всіх відомих жанрових форм, 
причому як академічної та масово-популярної, так і фольклорної галузей музичного мистецтва. Авторські ліричні інтенції приводять як до головної до стилістики романсу, але вона завжди змішується з ознаками фольклорного і аматорського пісенного жанру, насичується прийомами баладних форм, доростає до рівня синтетичної музичної композиції завдяки розвиненому інструментальному супроводу. Так, Т. Кирилівська пише, що інструментальна партія в творах В. Івасюка нерідко має самостійне звучання тоді, коли «...відтворює те, що недоступно вокальній мелодії: картини природи, жанрові штрихи і тощо», як це відбувається в піснях «Кленовий вогонь», «Водограй», «Літо пізніх жоржин», «Кораблі, кораблі», «В тебе тільки раннє літо», «Балада про дві скрипки» [3, 123].

Звернення до композиції і тексту музичного твору дозволяє прояснити природу стильової гри в музиці В. Івасюка; механізми стильової музичної гри дозволяють виявляти категорізацію понять часу та «героя свого часу» у творчості В. Івасюка. У зв'язку з цим відзначимо, що явище «стильової моделі» (як предмета ноематичної «гри») $е$ складним та вказує на опосередкованість стильового змісту. Стильові настанови розкриваються через стилістичні складові музичної мови, самодостатність структурного плану композиції. Останній осягається найбільш безпосередньо як композиційно-опусна постійна «поверхня» музичного задуму, стаючи началом «великої гри» зі смислом. Авторська семантика, однак, сприймається як певні естетичні інтенції, вже за межами конкретної композиційної роботи, є наслідком стильової метонімічності музики, тобто постає трансцендентною відносно конкретного матеріалу. Так, використовуючи стилістично-композиційні прикмети окремих жанрів та поєднуючи їх в композиційному розгортанні авторського цілісного тексту, Івасюк створює полістилістичну неостильову семантичну модель сучасної популярної пісні, що живиться просвітницькими мотивами та класицизуючими ідеями.

Дані обгрунтування неокласичного методу В. Івасюка підтверджуються наступним. По-перше, предметно-смислова ноематична основа його творчості послідовно розширюється, стаючи в принципі необмеженою. 3 процесом розширення сфери музично-текстових інтересів пов'язані і зміни в поетичній тематиці, також зростання ваги власних поетичних текстів, тобто повне авторськое охоплення жанрової території пісенного мистецтва.

Композитору вдається поєднати семантичні ознаки українського фольклору й академічної європейської музики (з притаманною їй єд- 
ністю духовного та світського параметрів) з деякими прийомами рокта поп-музики, вивести даний жанрово-системний синтез на рівень нової популярної класики. Остання не стільки утворюється класичними тенденціями в їх історичному розумінні музичної творчості, скільки відроджує (відновлює) романтичний досвід вирішення загальних важливих соціальних питань засобами індивідуалізованої та інтимно зумовленої, особистісно відзначеної музично-поетичної лірики.

Ноематичною передумовою тут виступає прагнення здолати історичну дистанцію між минулим та сьогоденням музичної традиції, змістову дистанцію між «високою» академічною музикою та «профанними» прикладними мистецькими формами, виробити єдину мову так званої «громадянської лірики» в музиці, таким чином повернути музиці в іiї неодмінній взаємодії з поетичним словом значення провідної форми людського співчуття та взаєморозуміння.

Дана, по своєму «ностальгічна», стильова ідея стає спонукальною причиною і метою смислотворчого діалогу в пісенному мистецтві В. Івасюка. Цей діалог може залишати враження міжжанрового та міжавторського, але завжди відбувається певним композиційно-стилістичним шляхом, з семантичним поглибленням пісенно-мовних структур. Своєрідність неокласичної позиції В. Івасюка можна визначати також антиномією «колишнього» - «не-колишнього» (одна з провідних антиномій пам'яті в теорії Л. Виготського [2]). 3 одного боку, в якості сукупності автономно-логічних форм музики музичний текст є «колишнім», що вже відбувся, претендує на незмінність і навіть канонічність. 3 іншого боку, в якості пред’явника живої стильової інтонації, особистісних смислів авторський текст є ідеально-утопічним, бо несе у собі умовні хронотопи. Творча уява композитора дозволяє йому вільно міняти не лише синтагми з вже готових музичних текстів, а й їх образні функції та композиційні положення. Тому діалогічна позиція Івасюка не обмежується ностальгічними спогадами, а визначається активним втручанням у зміст художньої моделі.

Ставлення до чужого досвіду творчості як до «готового знання», в якому нічого не можна (і не потрібно - воно вже є найкращим) міняти, викликає ностальгічну форму діалогу, здатну дійти до діалогу «за замовчуванням» - мовчазної згоди з тим, що вже було «сказано». Дана тенденція композиторського діалогу найбільше сприяла виникненню особливої галузі «музики тиші», медитативної лірики. Але в музиці В. Івасюка головний зміст визначається динамікою тематичних і фактурно-інтонаційних змін, образами руху в їх і широкому, i 
цілком музично-ситуативному значенні. Ідея руху як панівного стану життя, свідомості, почуття, відносин тощо стає синонімічною до ідеї часу та суголосною розумінню сучасності - як творчої позиції особистості відносно смислової виповненості власного життя.

У зв'язку зі сказаним пропонуємо уточнення поняття стильового мислення, що полягає у визначенні двох його складових. Першу утворює мнемонічний хід спогад, в процесі якого завжди змінюється та заново впорядковується згадуваний матеріал, активно-фамільярно присвоюється чужий досвід. Інша виникає з прогнозування, тобто з висловлення нових художніх пропозицій, без посилання на прецеденти, стосовно смислової реальності, в якій здатна опинитися творча особистість, таким чином постає свого роду «спогадами про майбутнє», тобто представленням майбутнього, у тому числі майбутнього музичного діяння, як того, що вже відбулося і увійшло до скарбниці культурної пам'яті. Його смисловою метою (ноематичним завданням) є досягнення позитивного емоційного підйому свідомості, причому незалежно від «знака» поточної емоції, гранично вираженого в співпереживанні любові (вищому позитивному стані прийняття світу як суб’єкта особистісного діалогу).

Стильове мислення у сфері популярного пісенного мистецтва базується на взаємодії двох форм музичного тексту - письмової та усної, зі своєрідним обміном герменевтичними контекстами між ними, з трансляцією авторських прав від композитора виконавцю і навпаки, що особливо яскраво виявлено тоді, коли композитор є найбільш успішним та відомим виконавцем власних творів.

Таким чином, наукова новизна роботи зумовлюється розвитком ноематичного напряму вивчення музичного стилю, визначенням своєрідності ноематичних координат авторської популярно-пісенної творчості, категорізацією понять часу та «героя свого часу» у відповідності до стилю В. Івасюка, уточненням поняття стильового мислення.

Висновки вказують на виявлення смислової предметності стилістичних означень та стильових узагальнень, головних діалогічних стильових тенденцій пісенної творчості В. Івасюка.

\section{СПИСОК ЛИТЕРАТУРЫ}

1. Бахтин М. Проблема текста в лингвистике, филологии и других гуманитарных науках // М. Бахтин. Эстетика словесного творчества. М.: Искусство, 1986. С. 297-325. 
2. Выготский Л. Проблема сознания // Л. С. Выготский. Собр. соч. в 6 томах / под ред. А. Лурия, М. Ярошевского. М.: Педагогика, 1982. Т.1. С. 156167.

3. Кириловська Т. Романсова основа його пісень // Володимир Івасюк. Життя - як пісня: спогади та есе / упоряд. Парасковія Нечаєва. Чернівці, 2003. C. $80-123$.

4. Колубаєв О. Л. Галицька популярна пісня в процесі еволюції регіональної традиції естрадно-музичного мистецтва: автореф. дис.... канд. мистецтвознавства; спец. 17.00.03 - муз. мистецтво. Одес. нац. муз. акад. ім. А. В. Нежданової. Одеса, 2014. 20 с.

5. Леви-Стросс К. Из книги «Мифологичные. І. Сырое и вареное» / ред. Лотман Ю. М., Петров В. М. // Искусствометрия: Методы точных наук и семиотики. Изд.4, стереот. 2009. С. 12-68.

6. Леонтьев Д. Психология смысла: природа, строение и динамика смысловой реальности. М. : Смысл, 2007. 1122 с.

7. Лосев А. Форма, стиль, выражение. М.: Мысль, 1995. 940 с.

8. Марищак В. На вершинах естрадної пісні // Володимир Івасюк. Життя - як пісня: спогади та есе / упоряд. Парасковія Нечаєва. Чернівці, 2003. C. 41-79.

9. Рябуха Т. Витоки та інтонаційні складові української пісенної естради: дис. ... канд. мистецтвознавства: спец. 17.00.03 - муз. мистецтво. Харків, 2017. $203 \mathrm{c}$.

10. Самойленко А. Музыковедение и методология гуманитарного знания. Проблема диалога. Одесса: Астропринт, 2002. 243 с.

\section{REFERENCES}

1. Bakhtin, M. (1968) The problem of text in linguistics, philology and other humanities // M. Bakhtin. Aesthetics of verbal creativity. P. 297-325. M.: Art. [in Russian].

2. Vygotsky, L. (1982) The Problem of Consciousness. Vygotsky. Coll. op. in 6 volumes / Ed. A. Luria, M. Yaroshevsky. T.1. P. 156-167. M.: Pedagogy [in Russian].

3. Kirilovska, T. (2003). Romance based on his songs. Volodymyr Ivasyuk. Life is like a song: memories and essays, 80-123. Chernivtsi [in Ukrainian].

4. Kolubayev, O. (2014). Galitskaya popular song in the process of evolution of the regional tradition of variety music art. Extended abstract of candidate's thesis. Odessa [in Ukrainian].

5. Levi-Strauss, K. (2009) From the book «Mythological. I. Raw and boiled»/ Ed. Lotman Yu.M., Petrov V. M. // Artometry: Methods of exact sciences and semiotics. P. 12-68 [in Russian].

6. Leontiev, D. (2007). Psychology of meaning: nature, structure and dynamics of semantic reality. 1122 p. M.: Sense [in Russian].

7. Losev, A. (1995). Form, style, expression. 940 p. Moscow: Thought. [in Russian].

8. Marishchak, V. (2003). At the top of the pop song. Life is like a song: memories and essays, 41-79. Chernivtsi [in Ukrainian]. 
9. Ryabukha, T. (2017). Origins and Intonational Components of Ukrainian Songbook. Candidate's thesis. Kharkiv [in Ukrainian].

10. Samoylenko, A. (2002). Musicology and methodology of humanitarian knowledge. The problem of dialogue. 243 p. Odessa: Astroprint [in Russian].

Стаття надійила до редакції 14.06.2016

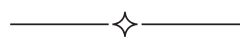

УДК 78.01+781.68/786.2

Ганна Святославівна Езерська, здобувач кафедри історії музики та музичної етнографії

ОНМА ім. А. В. Нежданової ezerskay88mir@mail.ru

\title{
ЯВИЩЕ ІНТЕРПРЕТАЦІЇ У ДЗЕРКАЛІ МУЗИКОЗНАВЧОГО ДИСКУРСУ
}

\begin{abstract}
Мета статті - розкрити зміст та значення музикознавчого внеску до теорії інтерпретації як міждисциплінарної галузі гуманітарного знання, виявити взаємозумовленість текстології та інтерпретології, довести актуальність та проблемну широту особистісно-стильового підходу до явища виконавської інтерпретації. Методологія роботи дозволяє поєднувати філософсько-герменевтичний, текстологічний та музикознавчий ракурси дослідження, виокремлювати музично-виконавський бік інтерпретологічної проблематики. Наукова новизна статті зумовлена розкриттям специфічних музикознавчих сторін проблеми інтерпретаціі в їі сучасному теоретичному стані, методичного значення музично-виконавського стильового вивчення процесу інтерпретації як засадничого у створенні художньо-виразової системи музики на різних стадіях історичного існування та структурно-семантичних рівнях. Висновки. Доводиться, що феномен інтерпретації має особливо рельєфне та цілісне вираження в музичному мистецтві завдяки його переважаючій виконавській природі та усно-семіотичним засобам діяння. Розкривається значення музичної інтерпретації як глибинно-психологічного процесу, який скерований до активізації та експлікації позитивних естетичних чинників людської свідомості, задіює архетипові чуттєві стани, що забезпечують креативні стильові можливості процесу розуміння в його широкому життетворчому та специфічному музично-виразовому призначенні.

Ключові слова: інтерпретація, музикознавча інтерпретологія, розуміння, музичне мистецтво, музично-виконавська інтерпретація, особистісно-стильовий підхід, усно-семіотичні музичні засоби.
\end{abstract}

